\title{
Neonicotinoid Residues in Sugar Beet Plants and Soil under Different Agro-Climatic Conditions
}

\author{
Helena Viric Gasparic ${ }^{1, * \mathbb{D}}$, Mirela Grubelic ${ }^{2}$, Verica Dragovic Uzelac ${ }^{3}$, Renata Bazok ${ }^{1}{ }^{1}$, \\ Maja Cacija ${ }^{1}$ D, Zrinka Drmic ${ }^{1,4}$ (D) and Darija Lemic ${ }^{1}(\mathbb{D}$ \\ 1 Department of Agricultural Zoology, Faculty of Agriculture, University of Zagreb, Svetosimunska Street 25, \\ 10000 Zagreb, Croatia; rbazok@agr.hr (R.B.); mcacija@agr.hr (M.C.); zrinka.drmic@hapih.hr (Z.D.); \\ dlemic@agr.hr (D.L.) \\ 2 Euroinspekt Croatiakontrola Ltd. for Control of Goods and Engineering, Karlovacka 4 L, 10000 Zagreb, \\ Croatia;mgrubelic@croatiakontrola.hr \\ 3 Department of Food Engineering, Faculty of Food Technology and Biotechnology, University of Zagreb, \\ Pierottijeva Street 6, 10000 Zagreb, Croatia; vdragov@pbf.hr \\ 4 Croatian Agency for Agriculture and Food, Vinkovačka Street 63c, 31000 Osijek, Croatia \\ * Correspondence: hviric@agr.hr; Tel.: +385-12393804
}

Received: 28 September 2020; Accepted: 15 October 2020; Published: 19 October 2020

\begin{abstract}
European sugar beet was mostly grown from seeds treated by neonicotinoids which provided efficient control of some important sugar beet pests (aphids and flea beetles). The EU commission regulation from 2018 to ultimately restrict the outdoor application of imidacloprid, thiamethoxam, and clothianidin could significantly affect European sugar beet production. Although alternative insecticides (spinosad, chlorantraniliprole, neem) are shown to have certain effects on particular pests when applied as seed treatment, it is not likely that in near future any insecticide will be identified as a good candidate for neonicotinoids' substitution. The aim of this research is to evaluate residue levels (LC-MS/MS method) of imidacloprid and thiamethoxam applied as seed dressing in sugar beet plants during two growing seasons in fields located in different agro-climatic regions and in greenhouse trials. In 2015, 25 to 27 days post planting (PP) maximum of $0.028 \%$ of imidacloprid and $0.077 \%$ of thiamethoxam were recovered from the emerged plants, respectively. In 2016, the recovery rate from the emerged plants 40 days PP was $0.003 \%$ for imidacloprid and 50 days PP was up to $0.022 \%$ for thiamethoxam. There were no neonicotinoid residues above the maximum residue level in roots at the time of harvesting, except in case of samples from thiamethoxam variant collected from greenhouse trials in $2016(0.053 \mathrm{mg} / \mathrm{kg})$. The results of this research lead to the conclusion that the seed treatment of sugar beet leaves minimal trace in plants because of the complete degradation while different behavior has been observed in the two fields and a glasshouse trial regarding the residues in soil. Dry conditions, leaching incapacity, or irregular flushing can result in higher concentrations in soil which can present potential risk for the succeeding crops. The results of our study could provide additional arguments about possible risk assessment for seed treatment in sugar beet.
\end{abstract}

Keywords: sugar beet; degradation; residues; neonicotinoids; imidacloprid; thiamethoxam

\section{Introduction}

Sugar beet (Beta vulgaris var. saccharifera L.) is an economically viable crop produced mainly for white sugar. The world's leading sugar beet producers (France, Germany and Poland) account for almost $50 \%$ of total world production (111.7 million tons in 2016). However, only $20 \%$ of the world's sugar comes from sugar beet; $80 \%$ is produced from sugar cane [1]. Given the production technology and the length of the growing season of almost 180 days, sugar beet is considered the most intensive agricultural crop [2]. 
The economically important pests of South East Europe sugar beet include wireworms, pigmy mangold beetle, sugar beet and corn weevil, black beet weevil, alfalfa snout beetle, several species of noctuid moths, sugar beet flea beetle, aphids, and beet cyst nematode [3-11]. Their appearance depends on the region and the year.

Since the introduction of neonicotinoid seed treatment in the 1990s, there has been a strong decrease in insecticide use in Croatia [12]. Wireworms, aphids, and flea beetles were successfully controlled by neonicotinoid seed treatments $[7,13-15]$ so additional treatment was only required in the case of severe infestation of some foliar pests that cannot be successfully controlled with neonicotinoids (e.g., sugar beet weevil) [16]. In north-western Europe, only aphids require occasional control with foliar insecticides [17].

Seed treatment is a method that has brought many advantages to modern agriculture [18-24], although there are some negative effects as well. In heavy infestations the efficacy against wireworms and sugar beet weevil is weak, so additional protection measures are necessary [7]. It is often applied at higher rates [24] or when control is not even necessary.

The use of neonicotinoids has become a major controversy because of their negative effects on bees, other pollinators, and possibly other non-target organisms [25-27]. According to the available evidence and a risk assessment carried out by EFSA, the use of neonicotinoid pesticides (clothianidin, imidacloprid, and thiamethoxam) was severely restricted by European Commission (EC) in 2013 by the implementation of Directive 485/2013 [28]. The restriction applied to bee-friendly crops such as maize, oilseed rape, and sunflower, with the exception of greenhouse crops and the post-flowering treatment of certain crops, and to winter cereals. Based on the EFSA peer review of the pesticide risk assessment carried out for clothianidin [25], imidacloprid [26], and thiamethoxam [27], the Commission adopted on 30 May 2018, regulations banning completely the outdoor use of imidacloprid, clothianidin, and thiamethoxam to protect domestic honey bees and wild pollinators [29]. The only risk identified by EFSA for the treatment of sugar beet seeds with neonicotinoids was the risk of succeeding crop scenario [25-27].

In the succeeding crop scenario, the residues of neonicotinoids are expected to remain in the soil and be absorbed by the succeeding crop or weeds in the same field. Thus, if the significant concentrations of neonicotinoids were to remain in the soil after the growing season, they could be adsorbed by the succeeding crop (or weeds) from the soil and then the neonicotinoids could be found in pollen or excreted in guttation fluid.

The Commission has not considered the possibility of proposing further options in addition to the total ban on the treatment of sugar beet seed with neonicotinoids. This decision could endanger sugar beet production. The ban was justified by the fact that some ecologically more acceptable substitute chemicals (diamides) are effective in controlling the most serious pests and that tools to control most pests are available under integrated pest management (IPM). However, the arguments do not fully apply to all economically important pests that damage sugar beet production in all production areas in the EU.

Hauer et al. [17] discussed neonicotinoid seed treatments in European sugar beet cultivation with regard to their effectiveness against target pests and their impact on the environment. They proposed to develop monitoring systems and models to identify regions (and years) with a higher risk of occurrence of pests and to allow the use of insecticide seed treatments only when high pest pressure is likely. In their analysis, Hauer et al. [17] only looked at sugar beet production in northwestern European countries and did not consider the different climatic conditions and the occurrence of pests in eastern and southeastern Europe, where problems in production are mainly caused by flea beetles and sugar beet weevils. This fact makes their proposal even more important.

The aim of this research was to determine the residue levels of imidacloprid and thiamethoxam used as a seed treatment in sugar beet plants in different agroclimatic regions in order to estimate environmental risk and possible transfer to other crops. Greenhouse trials have been established in order to provide insight to neonicotinoid behavior in controlled conditions. 


\section{Materials and Methods}

\subsection{Field Site and Experimental Design}

\subsubsection{Field Site}

The two-year study was conducted in 2015 and 2016 on three different locations. Field trials were located in two distinct counties of Croatia, Virovitica-Podravina County in Lukač $\left(45^{\circ} 52^{\prime} 26^{\prime \prime} \mathrm{N}\right.$

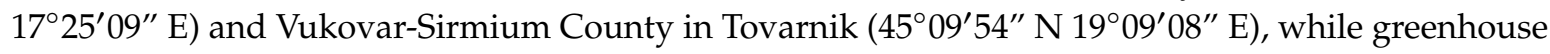
trial was set up in Zagreb at the Faculty of Agriculture, Department of Agricultural Zoology $\left(45^{\circ} 82^{\prime} 77^{\prime \prime} \mathrm{N}, 16^{\circ} 03^{\prime} 09^{\prime \prime} \mathrm{E}\right)$.

\subsubsection{Characteristics of the Soil}

To determine the physical and chemical soil properties in Lukač and Tovarnik, soil samples were taken in 2016 according to an internal protocol for annual crops provided by the Department of Plant Nutrition (University of Zagreb Faculty of Agriculture). At each site, 15 individual soil samples were taken on the same date from a depth of 0-30 cm, evenly distributed over the entire plot. A homogenized sample was prepared and $1.000 \mathrm{~g}$ were extracted for analysis. Chemical soil properties and texture analyses were carried out according to standard methods (ISO 112772004 ) in the pedological laboratory of the Department of Soil Science University of Zagreb Faculty of Agriculture.

\subsubsection{Climatic Data}

The data on climatic conditions were collected by Croatian Meteorological and Hydrological Service. The climatic conditions were monitored by the nearest climate stations (Virovitica for Lukač and Gradište for Tovarnik). The distance between the meteorological stations and the experimental sites was not more than $20 \mathrm{~km}$. For the period from April to September, data on mean air and soil temperatures and total precipitation were collected and analyzed for Virovitica and Gradište in both years under investigation.

\subsubsection{Design of Experiments}

At each site, sugar beet seed was sown in three treatments, one of which was untreated seed ( $0 \mathrm{mg}$ a.i./seed), the second treatment was sugar beet seed treated with imidacloprid (0.91 $\mathrm{mg}$ a.i./seed) and the third treatment was seed treated with thiamethoxam and teflutrin $(0.36+0.036 \mathrm{mg}$ a.i./seed $)$. In both years sowing was done in regular spring terms (2015: 9 April-Lukac, 10 April-Zagreb, 11 April-Tovarnik; 2016: 26 March-Tovarnik, 1 April-Lukac, 7 April-Zagreb). In field trials, each treatment was sown on $1.000 \mathrm{~m}^{2}$ in three repetitions. Each repetition was $123 \mathrm{~m}$ long and was sown with a six-row sowing harrow (i.e., $333 \mathrm{~m}^{2}$ ) at a depth of $3 \mathrm{~cm}$, the distance between rows was $45 \mathrm{~cm}$ and the distance in one row was $18 \mathrm{~cm}$ (i.e., 123,321 seeds/ha). In the greenhouse research the sowing conditions in the arable layer $(30 \mathrm{~cm})$ were simulated. The same treatments were sown in plastic containers of $90 \mathrm{~cm} \times 50 \mathrm{~cm} \times 38 \mathrm{~cm}$ (length $\times$ width $\times$ height) filled with 100 L Klasmann-Deilmann $\mathrm{GmbH}$ Supstrat 1 (EN Standard). The substrate used was a mixture of white peat $\left(\mathrm{H}_{2}-\mathrm{H}_{5}\right)$ and black peat $\left(\mathrm{H}_{6}-\mathrm{H}_{8}\right)$ with a $\mathrm{pH}$ value $\left(\mathrm{H}_{2} \mathrm{O}\right)$ of 5.5-6.5 and 14:10:18 NPK fertilizer. The amount of heavy metal was significantly below the maximum permissible concentration. The sowing was done by hand at a depth of $3 \mathrm{~cm}$ and the distance between the seeds was $5 \mathrm{~cm}$ with an approximate quantity of 45 seeds per container. A total of six containers were sown per treatment ( 2 per repetition).

\subsection{Sampling}

\subsubsection{Sampling of Sugar Beet Plants}

Starting four weeks after sowing, sugar beet plant samples were collected every two weeks at all three locations during the two growing seasons (2015 and 2016). In the first four sampling periods, 
whole plants were collected. From the fifth sampling until the end of the experiment, the collected plants were divided into leaves and roots, which were analyzed separately. The last sampling concerned only the roots. Three samples were taken for each treatment. A total of 432 sugar beet samples were collected and analyzed for neonicotinoid residues. Each sample contained five plants with a minimum weight of $20 \mathrm{~g}$. The collected samples were carefully labeled and transported in portable coolers to an accredited laboratory for analysis.

\subsubsection{Sampling of Soil}

In order to determine neonicotinoid residues in the soil, two samples were taken once at each site from the depth of a plow layer $(30 \mathrm{~cm}$ ). In 2016, 15 sub-samples (each weighing $1.000 \mathrm{~g}$, depending on field size) were taken, pooled and homogenized at each site, and a subset of the pooled soil samples $(20 \mathrm{~g})$ from each treatment area was taken and stored in a freezer until analyzed.

\subsection{Sample Analysis}

\subsubsection{Neonicotinoid Residues Analysis in Sugar Beet Plants and Soil}

The determination of neonicotinoid residues in sugar beet plants and soil was performed by an accredited laboratory by liquid chromatography/tandem mass spectrometry (LC -MS/MS) using acetonitrile extraction and the QuEChERS method (EN 15662: 2008). The limit of quantification (LOQ) for this method is $0.01 \mathrm{mg} / \mathrm{kg}$. The neonicotinoids were extracted from the homogenized sample with acetonitrile. Neonicotinoids, imidacloprid, thiamethoxam, and clothianidin were determined using the LC -MS/MS technique applied to the filtered extract with the Agilent Technologies 6460 Triple Quad LC/MS apparatus. Thiamethoxam is converted to clothianidin in soil and plant tissues, therefore the thiamethoxam residues were determined as the sum of thiamethoxam and clothianidin [30].

\subsubsection{Statistical Analysis}

The data on neonicotinoid residues were analyzed by analysis of variance (ANOVA) using the AOV factorial method with two or three factors [31]. The first factor was location which was considered as a fixed factor because of a limited production area of sugar beet and characteristic weather conditions. The second factor was insecticide treatment and the third factor was the plant part. This factor was analyzed for sampling during the growing season, where leaves and roots were sampled separately. A Tukey post-hoc test was used to determine which mean values of the variants were significantly different after a significant test result $(p<0.05)$.

\section{Results}

\subsection{Climatic and Edaphic Conditions}

Our analyses confirmed earlier data published by other authors [32-35] that the average annual temperatures in Tovarnik (Table 1) are higher than in Lukač. Precipitation varied from place to place in one of the two years of investigation and confirmed earlier published data [32-35] that when comparing Lukač (west) and Tovarnik (east), temperatures increased while precipitation decreased in the eastern part.

In both years the mean air and soil temperatures in the area of Lukač were significantly lower compared to Tovarnik, and the precipitation was significantly higher in 2015 in the same place, while in 2016 the differences were not significant. Between the years studied (2015 vs. 2016) there were no significant differences between the climatic conditions at both locations. 
Table 1. Characteristics of the weather conditions prevailing at the two locations where the field investigations were carried out and the corresponding ANOVA results.

\begin{tabular}{|c|c|c|c|c|}
\hline \multirow{2}{*}{ Climatic Factor } & \multirow{2}{*}{ Location } & \multicolumn{2}{|c|}{ Year } & \multirow{2}{*}{$\operatorname{HSD}^{2}(p=5 \%)$} \\
\hline & & 2015 & 2016 & \\
\hline \multirow{3}{*}{$\begin{array}{l}\text { Mean air temperature }\left({ }^{\circ} \mathrm{C}\right) \\
\text { (April-September) }\end{array}$} & Lukač & $18.65 \pm 0.72 b^{*}$ & $18.16 \pm 0.59 b$ & ns \\
\hline & Tovarnik & $19.85 \pm 0.75 a$ & $19.15 \pm 0.56 \mathrm{a}$ & ns \\
\hline & $\operatorname{HSD}(p=5 \%)$ & 0.338 & 0.325 & \\
\hline \multirow{3}{*}{$\begin{array}{l}\text { Mean soil temperature }\left({ }^{\circ} \mathrm{C} \text { ) }\right. \\
\text { (April-September) }\end{array}$} & Lukač & $21.1 \pm 0.88 b$ & $20.5 \pm 0.75 b$ & ns \\
\hline & Tovarnik & $22.63 \pm 0.97 \mathrm{a}$ & $21.47 \pm 0.7 \mathrm{a}$ & ns \\
\hline & $\operatorname{HSD}(p=5 \%)$ & 0.676 & 0.517 & \\
\hline \multirow{3}{*}{$\begin{array}{l}\text { Total amount of precipitation } \\
\text { (mm) (April-September) }\end{array}$} & Lukač & $600.03 \pm 68.02 a$ & $457.80 \pm 34.99$ & ns \\
\hline & Tovarnik & $309.72 \pm 40.05 b$ & $395.25 \pm 30.62$ & ns \\
\hline & $\operatorname{HSD}^{1}(p=5 \%)$ & 236.82 & ns & \\
\hline
\end{tabular}

${ }^{*}$ Values followed by the same lowercase letters are not significantly different ( $p>0.05$; HSD test), ${ }^{1}$, small letters refer to no differences among locations; ${ }^{2}$, small letters refer to no differences among years within same location; ns, letters refer to no differences.

The edaphic conditions differed between the locations. The soil in Tovarnik has a higher content of soil organic matter than the soil in Lukač (Table 2). In addition, both soils are classified as silty clay according to the soil particle size fractions. A detailed description of the regional physical and chemical soil properties is given in Table 2 .

Table 2. Physical and chemical soil properties in Lukač and Tovarnik, 2016.

\begin{tabular}{|c|c|c|c|c|c|c|c|c|c|c|c|c|}
\hline \multirow{2}{*}{\multicolumn{6}{|c|}{ Particle Size Distribution (\%) in mm }} & \multicolumn{7}{|c|}{ Chemical Soil Properties } \\
\hline & & & & & & \multicolumn{2}{|c|}{$\mathrm{pH}$} & \multicolumn{2}{|c|}{$\%$} & \multicolumn{2}{|c|}{ Al-mg/100 g } & \multirow{2}{*}{$\begin{array}{c}\mathrm{CaCO}_{3} \\
\%\end{array}$} \\
\hline & $\begin{array}{c}\text { Fine Sand } \\
0.2-0.063\end{array}$ & $\begin{array}{c}\text { Coarse Silt } \\
0.063-0.02\end{array}$ & $\begin{array}{c}\text { Fine Silt } \\
0.02-0.002\end{array}$ & Clay $<0.002$ & $\begin{array}{l}\text { Texture } \\
\text { Mark }\end{array}$ & $\mathrm{H}_{2} \mathrm{O}$ & $\mathrm{nKCl}$ & $\begin{array}{c}\text { Soil } \\
\text { Organic } \\
\text { Matter }\end{array}$ & $\mathbf{N}$ & $\mathrm{P}_{2} \mathrm{O}_{5}$ & $\mathrm{~K}_{2} \mathrm{O}$ & \\
\hline Lukač & 25.50 & 31.60 & 24.60 & 14.00 & Silty clay & 6.38 & 5.17 & 1.54 & 0.10 & 12.90 & 10.20 & 0.00 \\
\hline Tovarnik & 1.90 & 40.60 & 31.90 & 25.00 & Silty clay & 8.42 & 7.24 & 2.70 & 0.14 & 29.70 & 26.50 & 10.20 \\
\hline
\end{tabular}

\subsection{Degradation in Soil}

Table 3 shows that there were no residues of neonicotinoids above LOQ in Lukač. Tovarnik showed concentrations of imidacloprid residues above LOQ and slightly increased thiamethoxam, while higher residues were found in the greenhouse.

Table 3. Residues of neonicotinoids $(\mathrm{mg} / \mathrm{kg})$ in soil samples taken from field sites at the end of the growing season 2016 (i.e., 180 days' post planting), Croatia.

\begin{tabular}{cccc}
\hline Locality & Untreated & $\begin{array}{c}\text { Imidacloprid } \\
\mathbf{( m g / / k g )}\end{array}$ & $\begin{array}{c}\text { Thiamethoxam } \mathbf{( m g} / \mathbf{k g}) \\
\text { (Including Chlothianidin) }\end{array}$ \\
\hline Lukač & $<0.01$ & $<0.01$ & $<0.01$ \\
Tovarnik & $<0.01$ & 0.17 & 0.04 \\
Zagreb & $<0.01$ & 5.34 & 2.65 \\
\hline
\end{tabular}

\subsection{Degradation Dynamics in Plants}

Figure 1 shows a degradation dynamic of imidacloprid in sugar beet plants. 


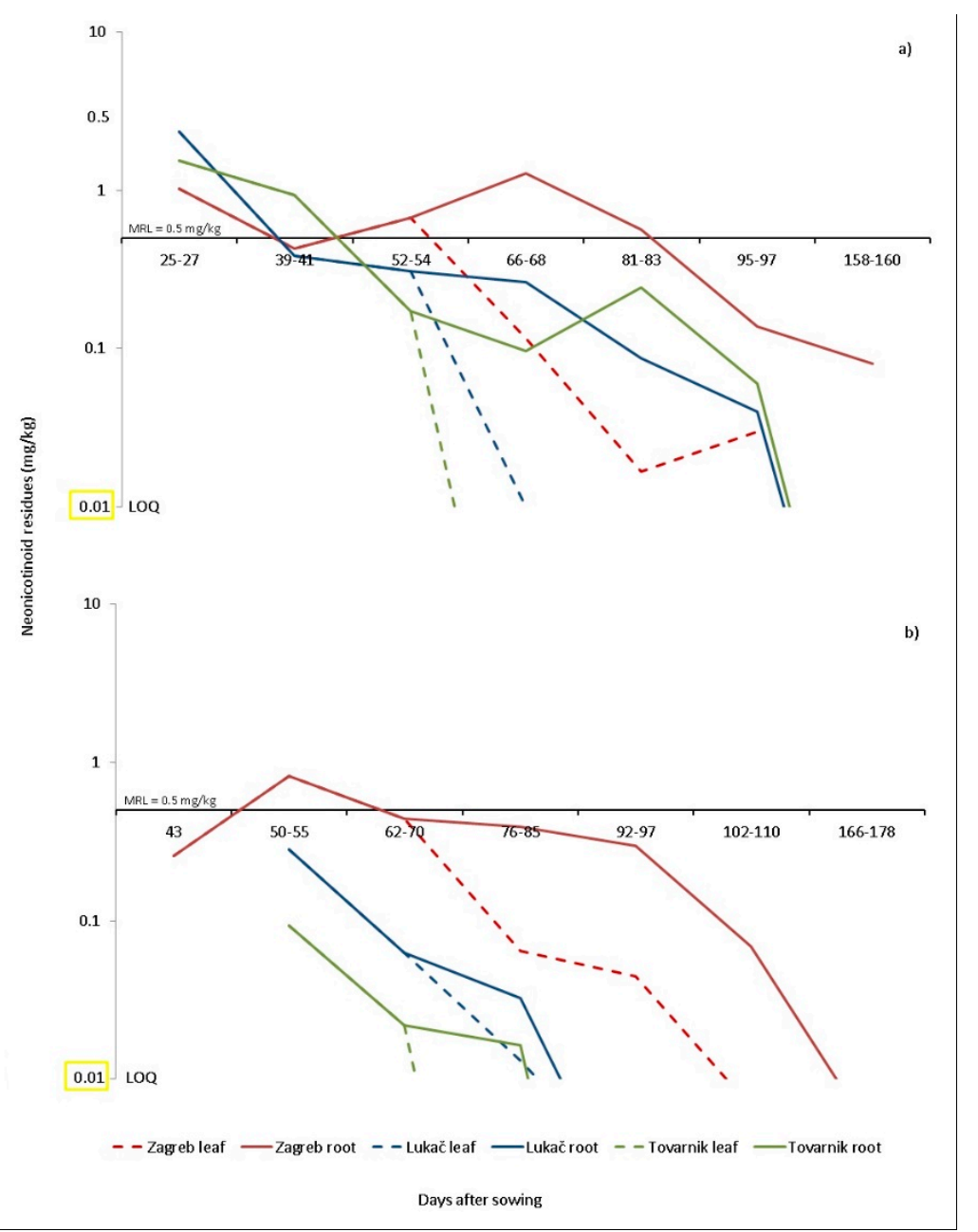

Figure 1. Degradation dynamics of imidacloprid during the growing seasons 2015 (a) and 2016 (b) in sugar beet plants in Lukac, Tovarnik and in greenhouse trials, in compliance with the maximum permitted residue level of $0.5 \mathrm{mg} / \mathrm{kg}$; LOQ— limit of quantification; MRL-maximum residue level.

The maximum residue level (MRL) for imidacloprid in sugar beet roots is $0.5 \mathrm{mg} / \mathrm{kg}$ (EU No 491/2014) [36]. Concentrations of imidacloprid in whole plants collected in field trials (Lukač and Tovarnik) fell below the MRL of $0.5 \mathrm{mg} / \mathrm{kg}$ (EU No. 491/2014) 40-55 days after sowing in both years under investigation [36] (Figure 1). After that, residues in the leaves of sugar beets grown under field conditions were almost no longer detectable. Root samples were taken 60 days after sowing, and from the first sample onwards the residue level in the roots was below the MRL. At the time of harvesting the roots (180 days after planting), no residues above LOQ were detected. In the greenhouse trial (Zagreb), degradation was much slower because no regular water rinsing was possible. Residues of imidacloprid in leaves from greenhouse trials fell below the MRLs ten days later compared to field conditions (i.e., 60 days after sowing). A slightly faster degradation of imidacloprid residues in roots of sugar beet grown in greenhouse trials was observed in 2016 compared to 2015. In general, the residue level of imidacloprid in roots was below the MRL 80 days after sowing. At the time of harvest, the residue level in roots was quite low, $0.08 \mathrm{mg} / \mathrm{kg}$ in 2015 and $<0.01 \mathrm{mg} / \mathrm{kg}$ in 2016 .

The results of the statistical analysis are presented in Tables 4-7. Residue levels were significantly affected by treatment with imidacloprid at almost all sampling times, except for two final samples where degradation was completed in both years of the study. Residue levels in plants from treated seeds were significantly higher compared to those in untreated plants throughout the vegetation until harvest where degradation was completed. In 2015, residues of imidacloprid were significantly influenced by 
location (i.e., agroclimatic conditions) in almost all but two of the last samples taken (Tables 4 and 5). In 2016, residues were significantly site-dependent (i.e., agroclimatic conditions) in only one sampling (76-85 days after sowing) when residues were significantly higher under greenhouse conditions in Zagreb (Tables 6 and 7). The third factor (plant part) was observed in three samples. In 2015, residues of imidacloprid were significantly affected in two out of three samples (Table 5), while in 2016 residues of plant parts were not affected at all (Table 7), confirming the good systemic translocation of imidacloprid.

Table 4. Imidacloprid residues in the whole sugar beet plants during the first three observing periods and for roots at harvesting in 2015.

\begin{tabular}{lccccc}
\hline & & \multicolumn{3}{c}{ Days after Sowing } \\
\cline { 3 - 5 } Source of Variation & $\mathbf{d f}$ & \multicolumn{3}{c}{ Whole Plant } & Root \\
\cline { 3 - 5 } & & $\mathbf{2 5 - 2 7}$ & $\mathbf{3 9 - 4 1}$ & $\mathbf{5 2 - 5 4}$ & $\mathbf{1 5 8 - 1 6 0}$ \\
\hline Total & 17 & & & & \\
Rep & 2 & & & & \\
Location (A) & 2 & $0.0079^{* *}$ & $0.0004^{* *}$ & $0.0048^{* *}$ & 0.0620 \\
Insecticide application (B) & 1 & $0.0001^{* *}$ & $0.0001^{* *}$ & $0.0001^{* *}$ & 0.0826 \\
A $\times$ B & 2 & $0.0901^{* *}$ & $0.0006^{* *}$ & $0.0063^{* *}$ & 0.0620 \\
Error & 10 & & & & \\
\hline
\end{tabular}

Analysis of variance for imidacloprid residues in the whole sugar beet plants and root. ${ }^{* *}$ significant at $p=0.01$.

Table 5. Imidacloprid residues in different plant parts during the vegetation period in 2015.

\begin{tabular}{lcccc}
\hline \multirow{2}{*}{ Source of Variation } & df & \multicolumn{3}{c}{ Days after Sowing } \\
\cline { 3 - 5 } & & $\mathbf{6 6 - 6 8}$ & $\mathbf{8 1 - 8 3}$ & $\mathbf{9 5 - 9 7}$ \\
\hline Total & 35 & & & \\
Rep & 2 & & & \\
Location (A) & 2 & $0.0001^{* *}$ & 0.1882 & 0.2633 \\
Insecticide application (B) & 1 & $0.0001^{* *}$ & $0.0087^{* *}$ & 0.1669 \\
A $\times$ B & 2 & $0.0001^{* *}$ & 0.1882 & 0.4588 \\
Plant part (C) & 1 & $0.0001^{* *}$ & $0.0127^{*}$ & 0.1964 \\
A $\times$ C & 2 & $0.0011^{* *}$ & 0.2117 & 0.3212 \\
B $\times$ C & 1 & $0.0001^{* *}$ & $0.0127^{*}$ & 0.1964 \\
A $\times$ B $\times$ C & 2 & $0.0015^{* *}$ & 0.2117 & 0.3212 \\
Error & 22 & & & \\
\hline
\end{tabular}

Analysis of variance for imidacloprid residues in different plant parts. ${ }^{*}$ significant at $p=0.05,{ }^{* *}$ significant at $p=0.01$.

Table 6. Imidacloprid residues in the whole plants during the first two observing periods and for roots at harvesting in 2016.

\begin{tabular}{|c|c|c|c|c|}
\hline \multirow{3}{*}{ Source of Variation } & \multirow{3}{*}{ df } & \multicolumn{3}{|c|}{ Days after Sowing } \\
\hline & & \multicolumn{2}{|c|}{ Whole Plant } & \multirow{2}{*}{$\begin{array}{c}\text { Root } \\
166-178\end{array}$} \\
\hline & & $50-55$ & $62-70$ & \\
\hline Total & 17 & & & \\
\hline Rep & 2 & & & \\
\hline Location (A) & 2 & 0.1380 & 0.1822 & 1.000 \\
\hline Insecticide application (B) & 1 & $0.0001^{* *}$ & 0.0135 * & 1.000 \\
\hline $\mathrm{A} \times \mathrm{B}$ & 2 & 0.1380 & 0.1822 & 1.000 \\
\hline Error & 10 & & & \\
\hline
\end{tabular}

Analysis of variance for imidacloprid residues in the whole sugar beet plants and root. ${ }^{*}$ significant at $p=0.05$, ** significant at $p=0.01$. 
Table 7. Imidacloprid residues in the different plant parts during the vegetation period in 2016.

\begin{tabular}{lcccc}
\hline \multirow{2}{*}{ Source of Variation } & $\mathbf{d f}$ & \multicolumn{3}{c}{ Days after Sowing } \\
\cline { 3 - 5 } & & $\mathbf{7 6 - 8 5}$ & $\mathbf{9 2 - 9 7}$ & $\mathbf{1 0 2 - 1 1 0}$ \\
\hline Total & 35 & & & \\
Rep & 2 & & & \\
Location (A) & 2 & $0.0001^{* *}$ & 0.1041 & 0.1346 \\
Insecticide application (B) & 1 & $0.0001^{* *}$ & $0.0106^{*}$ & $0.0087^{* *}$ \\
A $\times$ B & 2 & $0.0001^{* *}$ & 0.1041 & 0.1346 \\
Plant part (C) & 1 & 0.7046 & 0.1628 & 0.0517 \\
A $\times$ C & 2 & $0.0234^{*}$ & 0.5097 & 0.3246 \\
B $\times$ C & 1 & 0.7046 & 0.1628 & 0.0517 \\
A $\times$ B $\times$ C & 2 & $0.0234^{*}$ & 0.5097 & 0.3246 \\
Error & 22 & & & \\
\hline
\end{tabular}

Analysis of variance for imidacloprid residues in different plant parts. ${ }^{*}$ significant at $p=0.05,{ }^{* *}$ significant at $p=0.01$.

The significant interaction between all three factors (location $\times$ insecticide treatment $\times$ plant part) for the imidacloprid residue level was present at the first sampling when plant parts were sampled separately (i.e., 66-68 days after sowing in 2015 and 76-85 days after sowing in 2016). A significant insecticide "treatment $\times$ location" interaction for imidacloprid residues was not observed in the first and the last two samples in 2015 (Tables 4 and 5), while in 2016 the significant interaction was only observed when samples were taken 76 to 85 days after sowing (Tables 6 and 7). For all other sampling data, the significant interaction "insecticide treatment $\times$ location" did not exist for imidacloprid residues. Significant interactions between "location $\times$ plant part" and "insecticide application $\times$ plant part" for imidacloprid residues existed only occasionally in both years of the study.

Figure 2 shows a degradation dynamic of thiamethoxam (expressed as sum of thiamethoxam and clothianidin) in sugar beet plants.

The maximum residue level (MRL) for thiamethoxam and clothianidin has been reduced in Europe from $0.05 \mathrm{mg} / \mathrm{kg}$ to $0.02 \mathrm{mg} / \mathrm{kg}$ in 2017 (EU 2017/671) [37]. For sugar beets grown under field conditions, the residue content of thiamethoxam in the leaves and roots of sugar beets dropped below the MRL between 70 and 80 days after sowing, depending on the year and location (Figure 2). No residues were found in sugar beet roots in open field cultivation at the time of harvest.

Similar to imidacloprid, the degradation of thiamethoxam was much slower in greenhouse trials. The residues of thiamethoxam in sugar beet roots in greenhouse cultivation were above the MRL (i.e., $0.053 \mathrm{mg} / \mathrm{kg}$ ) at harvest time in 2015 (Figure 2), while in 2016, 100 days after sowing, the residues fell below the MRL of $0.02 \mathrm{mg} / \mathrm{kg}$ in 2016 .

The results of the statistical analysis are presented in Tables 8-11. Residue levels were significantly affected by thiamethoxam treatment at all sampling dates including the last sampling in 2015, indicating that degradation at harvest is not complete in all trials. At the time of harvest in 2015, residues $(0.053 \mathrm{mg} / \mathrm{kg}$ ) were confirmed in beet roots grown in greenhouses (see Figure 2). 


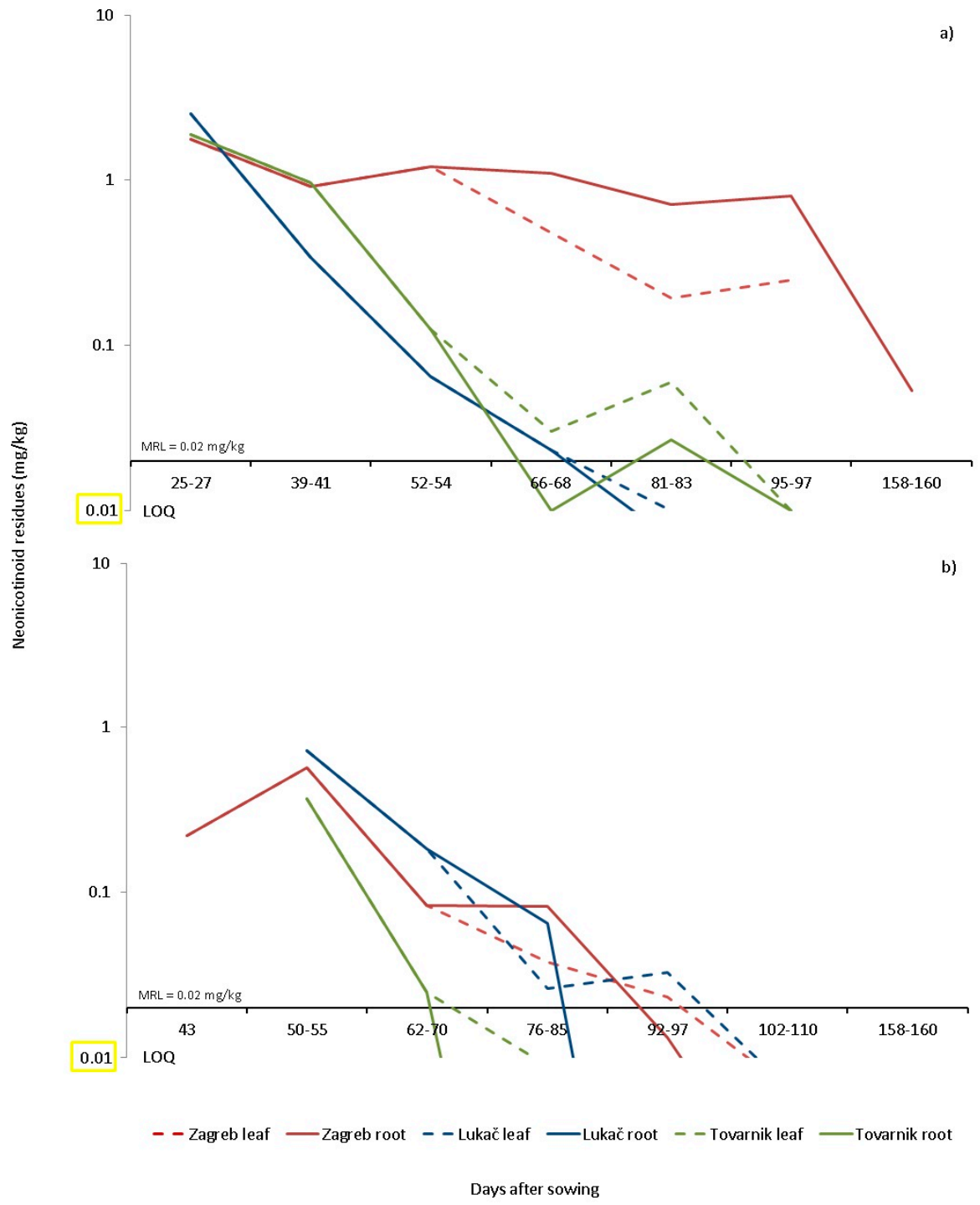

Figure 2. Degradation dynamics of thiamethoxam (expressed as sum of thiamethoxam and clothianidin) during the growing seasons 2015 (a) and 2016 (b) in sugar beet plants in Lukac, Tovarnik and in greenhouse trials, in compliance with the maximum permitted residue level of $0.02 \mathrm{mg} / \mathrm{kg}$; LOQ - limit of quantification; MRL_maximum residue level.

Table 8. Thiamethoxam (including chlothianidin) residues in the whole plants during the first three observing periods and for roots at harvesting in 2015.

\begin{tabular}{|c|c|c|c|c|c|}
\hline \multirow{3}{*}{ Source of Variation } & \multirow{3}{*}{ df } & \multicolumn{4}{|c|}{ Days after Sowing } \\
\hline & & \multicolumn{3}{|c|}{ Whole Plant } & \multirow{2}{*}{$\begin{array}{c}\text { Root } \\
158-160\end{array}$} \\
\hline & & $25-27$ & $39-41$ & $52-54$ & \\
\hline Total & 17 & & & & \\
\hline Rep & 2 & & & & \\
\hline Location $(\mathrm{A})$ & 2 & 0.1246 & $0.0025^{* *}$ & $0.0001^{* *}$ & $0.0003^{* *}$ \\
\hline $\begin{array}{l}\text { Insecticide application } \\
\text { (B) }\end{array}$ & 1 & $0.0001^{* *}$ & $0.0001^{* *}$ & $0.0001 * *$ & $0.0011^{* *}$ \\
\hline$A \times B$ & 2 & $0.0452 *$ & $0.0025^{* *}$ & $0.0001 * *$ & $0.0003^{* *}$ \\
\hline Error & 10 & & & & \\
\hline
\end{tabular}

Analysis of variance for thiamethoxam residues in the whole sugar beet plants and root. ${ }^{*}$ significant at $p=0.05$, ** significant at $p=0.01$. 
Table 9. Thiamethoxam (including chlothianidin) residues in different plant parts during the vegetation period in 2015 .

\begin{tabular}{lcccc}
\hline \multirow{2}{*}{ Source of Variation } & df & \multicolumn{3}{c}{ Days after Sowing } \\
\cline { 3 - 5 } & & $\mathbf{6 6 - 6 8}$ & $\mathbf{8 1 - 8 3}$ & $\mathbf{9 5 - 9 7}$ \\
\hline Total & 35 & & \\
Rep & 2 & & & \\
Location (A) & 2 & $0.0001^{* *}$ & $0.0001^{* *}$ & $0.0001^{* *}$ \\
Insecticide application (B) & 1 & $0.0001^{* *}$ & $0.0001^{* *}$ & $0.0001^{* *}$ \\
A $\times$ B & 2 & $0.0001^{* *}$ & $0.0001^{* *}$ & $0.0001^{* *}$ \\
Plant part (C) & 1 & $0.0049^{* *}$ & $0.0262^{*}$ & $0.0263^{*}$ \\
A $\times$ C & 2 & $0.0006^{* *}$ & $0.0002^{* *}$ & $0.0103^{*}$ \\
B $\times$ C & 1 & $0.0062^{* *}$ & $0.0262^{*}$ & $0.0263^{*}$ \\
A $\times$ B $\times$ C & 2 & $0.0006^{* *}$ & $0.0002^{* *}$ & $0.0103^{*}$ \\
Error & 22 & & & \\
\hline Analysis of variance for thiamethoxam residues in different plant parts * significant at $p=0.05 *$ sionificant at $p=0.01$
\end{tabular}

Analysis of variance for thiamethoxam residues in different plant parts * significant at $p=0.05,{ }^{* *}$ significant at $p=0.01$.

Table 10. Thiamethoxam (including chlothianidin) residues in the whole plants during the first three observing periods and for roots at harvesting in 2016.

\begin{tabular}{lcccc}
\hline & & \multicolumn{3}{c}{ Days after Sowing } \\
\cline { 3 - 4 } Source of Variation & df & \multicolumn{2}{c}{ Whole Plant } & Root \\
\cline { 3 - 5 } & & $\mathbf{5 0 - 5 5}$ & $\mathbf{6 2 - 7 0}$ & $\mathbf{1 6 6 - 1 7 8}$ \\
\hline Total & 17 & & & \\
Rep & 2 & & 0.1822 & 1.0000 \\
Location (A) & 2 & 0.1380 & $0.0135^{*}$ & 1.0000 \\
Insecticide application (B) & 1 & $0.0001^{* *}$ & 0.1822 & 1.0000 \\
A $\times$ B & 2 & 0.1380 & & \\
Error & 10 & & &
\end{tabular}

Analysis of variance for thiamethoxam residues in the whole sugar beet plants and root. * significant at $p=0.05$, ** significant at $p=0.01$.

Table 11. Thiamethoxam (including chlothianidin) residues in the different plant parts during the vegetation period in 2016.

\begin{tabular}{lcccc}
\hline \multirow{2}{*}{ Source of Variation } & df & \multicolumn{3}{c}{ Days after Sowing } \\
\cline { 3 - 5 } & & $\mathbf{7 6 - 8 5}$ & $\mathbf{9 2 - 9 7}$ & $\mathbf{1 0 2 - 1 1 0}$ \\
\hline Total & 35 & & \\
Rep & 2 & & \\
Location (A) & 2 & $0.0001^{* *}$ & $0.0255^{*}$ & 0.1346 \\
Insecticide application (B) & 1 & $0.0001^{* *}$ & $0.0007^{* *}$ & $0.0087^{* *}$ \\
A $\times$ B & 2 & $0.0001^{* *}$ & $0.0255^{*}$ & 0.1346 \\
Plant part (C) & 1 & 0.7046 & 0.0672 & 0.0517 \\
A $\times$ C & 2 & $0.0234^{*}$ & 0.1438 & 0.3246 \\
B $\times$ C & 1 & 0.7046 & 0.0672 & 0.0517 \\
A $\times$ B $\times$ C & 2 & $0.0234^{*}$ & 0.1438 & 0.3246 \\
Error & 22 & & & \\
\hline Anaysi of & & & \\
\hline
\end{tabular}

Analysis of variance for thiamethoxam residues in different plant parts. ${ }^{*}$ significant at $p=0.05,{ }^{* *}$ significant at $p=0.01$.

In 2016, residue levels were significantly affected by thiamethoxam treatment on all but the last sampling dates, indicating that degradation at harvest was complete under all conditions studied, including greenhouse trials. In 2015, residues of thiamethoxam were significantly influenced by location (i.e., agroclimatic conditions) at almost all sampling dates except the first sampling (Table 8). In 2016, residues were significantly influenced by the location (Tables 10 and 11) on only two samples (76-85 and 92-97 days after sowing), when residues were significantly higher under greenhouse 
conditions in Zagreb (Figure 2). The third factor (plant part) was observed in three samples. In 2015 the residues of thiacloprid were significantly influenced by plant parts in three samples (Table 9), whereas in 2016 the residues were not influenced by plant parts at all (Table 11). A significant insecticide "treatment $\times$ location" interaction for thiamethoxam residues was observed in 2015 in all samples (Tables 8 and 9), while in 2016 the significant interaction was observed in only two samples taken after 76-85 days and 92-97 days after sowing (Table 11). Significant interactions between "location $\times$ plant part" and "insecticide application $\times$ plant part" for thiacloprid residues were complete in 2015. In 2016, these interactions only existed on a single sampling date for the "location $\times$ plant part" interaction. The significant interaction between all three factors (location $\times$ insecticide treatment $\times$ plant part) for thiacloprid residue level existed in 2015 for all three samples and in 2016 for only one sample when plant parts were sampled separately (i.e., 76-85 days after sowing in 2016).

\section{Discussion}

When the neonicotinoids were introduced to the market, they were considered safe to use because they are stable in soil and have low toxicity to mammals [38]. However, recent studies have shown that neonicotinoids have adverse effects on bees, other pollinators, and possibly other non-target organisms [25-27]. A complete EU Commission Regulation ban on the outdoor use of imidacloprid, thiamethoxam, and clothianidin could have a significant impact on the practice of sugar beet production in Europe, as $100 \%$ of all commercial sugar beet seeds have been treated with neonicotinoids. According to Ester et al. and Lanka et al. [39,40] spinosad and chlorantraniliprole applied as seed treatment were ineffective at controlling flea beetles and cabbage aphid [39] as well as adult stages of rice water weevil [40]. It is unlikely that they will become a good substitute of neonicotinoid seed treatment. Hauer et al. [17] have pointed out the lack of effective alternatives for the control of M. persicae on sugar beet in Central and North Europe. Moreover, Bažok et al. [16] achieved the same conclusions for substituting control of sugar beet flea beetle in South and Eastern Europe. Therefore, the problems related to the control of the above mentioned pests could become a serious problem in the future if no alternatives are developed.

In our study, at the end of sugar beet cultivation (180 days after planting), imidacloprid residues at a concentration of $0.17 \mathrm{mg} / \mathrm{kg}$ and thiamethoxam residues at a concentration of $0.04 \mathrm{mg} / \mathrm{kg}$ were found in the soil of Tovarnik, while in Lukač all residues were below LOQ levels (Table 4). Such a result is partially consistent with that of [41] who randomly sampled 74 soils after the cultivation of maize, wheat, and barley grown from treated seeds. Imidacloprid was found in all samples, so the authors concluded that imidacloprid is always present in the soils after cultivation and is easily detectable if sampling is carried out in the year of treatment.

Alford and Krupke [42] concluded that high water solubility of neonicotinoid seed treatment applications makes it unlikely that they will remain near the relatively confined rhizosphere of the target plant long enough to be absorbed by the plant when not on the seed. The loss of neonicotinoids from agricultural soils is thought to occur through degradation or leaching in soil water [43]. EFSA's risk assessment [25-27] did not take into account the results of [42] on the low probability of residues of neonicotinoids remaining in soil for a longer period of time. Their findings, together with those of [44] on the recycling of neonicotinoid insecticides from contaminated groundwater back to crops, point to the possible risk scenario of irrigation, which will be further investigated. In our laboratory study, the sugar beet plants were sown at five times higher density than in the field, which means that the concentration of neonicotinoids is also significantly higher $(40.95 \mathrm{mg}$ imidacloprid and $32.76+$ $1.62 \mathrm{mg}$ thiamethoxam + teflutrin per container 1001 soil). Soil from greenhouse trials treated with imidacloprid contained the average value of $5.34 \mathrm{mg} / \mathrm{kg}$ a.i., while the thiamethoxam-treated variant of the sample form contained $2.65 \mathrm{mg} / \mathrm{kg}$ a.i. (Table 4). This is much higher if we consider that in open field the application rate as seed coating is $112.2 \mathrm{~g}$ imidacloprid or $44.4+4.44 \mathrm{~g}$ thiamethoxam + tefluthrin to one ha, while one ha contains on average three million liters of soil (calculation of the average soil layer of $30 \mathrm{~cm}$ ). This is the average concentration of $0.04 \mathrm{mg} / \mathrm{kg}$ a.i. imidacloprid or 
$0.015+0.0015 \mathrm{mg} / \mathrm{kg}$ thiamethoxam + tefluthrin. Our result confirms that high concentrations of neonicotinoids in soil are to be expected in case of dry conditions, leaching incapacity, or irregular flushing (bottom of the container) into ground water meaning that they can present potential risk for the succeeding crops. Concerning field trials, there is no systematic monitoring of the presence of pesticides in water in Croatia and no data on concentrations of neonicotinoids in the area of our study are available.

Studies on the degradation of neonicotinoids in soil depend on temperature, moisture, and soil type, in particular on texture and organic matter content, $\mathrm{pH}$ and UV radiation [41]. According to Bonmatin [41], persistence is highest under cool, dry conditions and in soils with high organic matter content. On average, Lukač has more precipitation (more humid soil), lower soil and air temperatures, while Tovarnik is drier with low precipitation and slightly higher air and soil temperatures (Table 2). Table 3 shows that in our investigations the $\mathrm{pH}$ of the soil at both locations was between 5 and 7 , which means that the soils are slightly acidic to neutral and do not allow degradation in the moist soil or water. Guzsvány et al. [45] found that imidacloprid and thiamethoxam degrade faster at $23{ }^{\circ} \mathrm{C}$ in alkaline media, while they remain relatively stable at $\mathrm{pH} 7$ and 4 . Regarding residues of neonicotinoids in soil after the vegetation period, Table 3 shows that all residues were lower than LOQ in Lukač while in Tovarnik $0.17 \mathrm{mg} / \mathrm{kg}$ imidacloprid and $0.04 \mathrm{mg} / \mathrm{kg}$ thiamethoxam were detected. Such results can be explained by the dry conditions, low precipitation, and slightly higher air and soil temperatures prevailing in Tovarnik. The soils of Tovarnik also contain a large amount of soil organic matter as well as available phosphorus and potassium (Table 3), which prevents the leaching of residues and allows higher sorption in soils with high organic matter content, which is also in line with the results of [46]. Even though the results of the residues in soil are not statistically assessed, we may conclude that the faster reduction of residues in Lukač is most likely due to higher precipitation which is confirmed with the analyses of the residues in plants. The presence of a significant "treatment $x$ location" (i.e., agroclimatic conditions) interaction for thiamethoxam in 2015 (when locations differ in temperature and precipitation) and the absence of a significant interaction for the same factors in 2016 (when locations differ only in temperature) implies that precipitation is an important factor in thiamethoxam leaching. The same logic could not be followed for the degradation of imidacloprid because there was a significant "treatment $\times$ location" (i.e., agroclimatic conditions) interaction for imidacloprid residues only in three out of seven samples in 2015 and in one out of six samples in 2016.

According to Bonmatin et al. [41], the half-life of imidacloprid for seed treatment in France was about 270 days, while [47] reported 83 to 124 days under field conditions and 174 days on bare soil. Under field conditions, thiamethoxam showed a moderate to fast degradation rate [48]. The calculated half-life in soil was between 7 and 335 days for thiamethoxam [49].

Uptake by the roots ranged from 1.6 to $20 \%$ for imidacloprid in aubergines and maize [50]. Krupke et al. [50] pointed out that the uptake of clothianidin by maize plants was relatively low and that plant-bound clothianidin concentrations followed an exponential decay pattern with initially high values, followed by a rapid decrease within the first 20 days after planting. A maximum of $1.34 \%$ of the initial seed treatment rate (calculated as $\mathrm{mg}$ a.i./ $/ \mathrm{kg}$ of seed) was successfully obtained from plant tissues (calculated as $\mathrm{mg}$ a.i. $/ \mathrm{kg}$ of plant tissue) and a maximum of $0.26 \%$ from root samples. Our study showed that 25 days to 27 days after planting in 2015, a maximum of $0.028 \%$ imidacloprid and $0.077 \%$ thiamethoxam was obtained from the raised plants (Figures 1 and 2). In 2016, the recovery rate from the raised plants 40 days after planting was $0.003 \%$ for imidacloprid and 50 days after planting up to $0.022 \%$ for thiamethoxam. These data confirm that the degradation scenario of imidacloprid and thiamethoxam in sugar beet crops is similar to the scenario established for clothianidin by [50].

Westwood et al. [51] found that the concentration of imidacloprid in the leaves of sugar beet grown from treated seed was $15.2 \mathrm{mg} / \mathrm{kg} 21$ days after planting and degradation to $0.5 \mathrm{mg} / \mathrm{kg} 97$ days after planting (25-leaf stage). Bažok et al. [52] found twice as high a concentration of $0.95 \mathrm{mg} / \mathrm{kg}$ imidacloprid in sugar beet leaves 42 days after planting using the HPLC method. Compared to HPLC, the LC -MS/MS method has a lower limit of determination (LOQ) and offers the possibility of a clear 
identification of the analyte [53]. Therefore, our results show more precise results confirming that there are no residues of neonicotinoids in the roots of sugar beet during harvest time. Nevertheless, the risk is not negligible in dry climates or after a dry period since results showed higher soil concentrations of imidacloprid than expected in Tovarnik. Results have shown [47] that field trials in Europe and the United States on the degradation of imidacloprid show that it does not accumulate in soil after repeated annual applications. Although sugar beet in Croatia is grown in crop rotation where neonicotinoids are already prohibited (maize, oilseed rape, wheat, etc.), there should be a limited risk of bioaccumulation and transfer to other crops but the risk for succeeding crops needs to be further assessed.

Neonicotinoid seed treatment of sugar beet is still allowed in many other regions of the world (except the EU). Increase in the wide use of insecticides, in particular pyrethroid insecticides, against aphids and flea beetles (depending on the growing area) is expected in areas where neonicotinoids are banned. The status of neonicotinoids for sugar beet seed treatment will possibly be further investigated by various regulatory authorities around the world.

\section{Conclusions}

The residue levels of imidacloprid and thiamethoxam used for seed treatment of sugar beet plants were below the maximum permitted residue level at the time of harvest and were highly dependent on weather conditions, in particular rainfall. The results of this research show that the seed treatment of sugar beet leaves minimal trace in plants because of the complete degradation by the end of the growing season while higher residue concentration in the soil shows that there is risk in dry climates or after a dry period. The results of our study provide additional arguments for a possible risk assessment for sugar beet seed treatment in the succeeding crop and irrigation scenarios and provide further guidance for the assessment and/or reassessment of the use of neonicotinoids in sugar beet production. However, further investigation is needed to assess the possible neonicotinoids uptake by succeeding crops.

Author Contributions: Conceptualization, R.B.; data curation, H.V.G. and Z.D.; formal analysis, M.G. and R.B.; funding acquisition, R.B.; investigation, H.V.G., M.C., Z.D., and D.L.; methodology, M.G. and R.B.; project administration, H.V.G.; supervision, V.D.U. and R.B.; visualization, H.V.G. and Z.D.; writing-original draft, H.V.G.; writing - review and editing, V.D.U., R.B., and D.L. All authors have read and agreed to the published version of the manuscript.

Funding: This research was supported by the European Social Fund within the project "Improving Human Capital by Professional Development through the Research Program in Plant Medicine" [HR.3.2.01-0071].

Acknowledgments: We thank Detlef Schenke and Martina Hoffman from the JKI Institute in Berlin for collaboration and support regarding residue analyses.

Conflicts of Interest: The authors declare no conflict of interest.

\section{References}

1. Eurostat. Available online: http://ec.europa.eu/eurostat/statistics-explained/index.php/Agricultural_production_ -_crops\#Potatoes_and_sugar_beet (accessed on 13 July 2018).

2. Pospišil, M. Ratarstvo II. dio-Industrijsko Bilje; Zrinski: Čakovec, Croatia, 2013; pp. 222-227.

3. Čamprag, D. Najvažnije Štetočine Šécerne Repe u Jugoslaviji, Mađarskoj, Rumuniji i Bugarskoj, sa Posebnim osvrtom na Važnije Štetne Vrste; Poljoprivredni Fakultet, Institut za Zaštitu Bilja Novi Sad: Novi Sad, Serbia, 1973; pp. 343-352.

4. Drmić, Z. Repin buhač. In Šećerna Repa: Zaštita od Štetnih Organizama u Sustavu Integrirane Biljne Proizvodnje; Bažok, R., Ed.; Sveučilište u Zagrebu Agronomski Fakultet: Zagreb, Croatia, 2015; pp. 42-44.

5. Čuljak, T.G. Lisne uši. In Šećerna Repa: Zaštita od Štetnih Organizama u Sustavu Integrirane Biljne Proizvodnje; Bažok, R., Ed.; Sveučilište u Zagrebu Agronomski Fakultet: Zagreb, Croatia, 2015; pp. 44-49.

6. Grubišić, D. Repina nematoda. In Šećerna Repa: Zaštita od Štetnih Organizama u Sustavu Integrirane Biljne Proizvodnje; Bažok, R., Ed.; Sveučilište u Zagrebu Agronomski Fakultet: Zagreb, Croatia, 2015; pp. 55-58.

7. Igrc Barčić, J.; Dobrinčić, R.; Šarec, V.; Kristek, A. Investigation of the Insecticide Seed Dressing on the Sugar Beet. Agric. Conspec. Sci. 2000, 65, 89-97. 
8. Lemić, D. Sovice pozemljuše. In Šećerna Repa: Zaštita od Štetnih Organizama u Sustavu Integrirane Biljne Proizvodnje; Bažok, R., Ed.; Sveučilište u Zagrebu Agronomski Fakultet: Zagreb, Croatia, 2015; p. 35.

9. Lemić, D. Lisne sovice. In Šećerna repa: Zaštita od Štetnih Organizama u sustavu Integrirane Biljne Proizvodnje; Bažok, R., Ed.; Sveučilište u Zagrebu Agronomski Fakultet: Zagreb, Croatia, 2015; pp. 49-50.

10. Lemić, D. Repin moljac. In Šećerna Repa: Zaštita od Štetnih Organizama u Sustavu Integrirane Biljne Proizvodnje; Bažok, R., Ed.; Sveučilište u Zagrebu Agronomski Fakultet: Zagreb, Croatia, 2015; pp. 50-55.

11. Sekulić, R.; Kereši, T. Da li Treba Hemijski Suzbijati Repinog Moljca? Naučni Institut za ratarStvo i Povrtlarstvo: Novi Sad, Serbia, 2003; p. 38.

12. Bažok, R.; Buketa, M.; Lopatko, D.; Ljikar, K. Suzbijanje štetnika šećerne repe nekad i danas. Glas. Biljn. Zašt. 2012, 12, 414-428.

13. Altmann, R. Gaucho, a new insecticide for controlling beet pests. Pflanzenshutz Nachr. Bayer 1991, 44, $159-174$.

14. Elbert, A.; Nauen, R.; Cahill, M.; Devonshire, A.L.; Scarr, A.W.; Sone, S.F. Resistance management with chloronicotinyl insecticides using imidacloprid as an example. Pflanzenschutz-Nachr. Bayer (English ed.) 1996, 49, 5-54.

15. Dobrinčić, R. Prednosti i nedostaci tretiranja sjemena ratarskih kultura insekticidima. Glas. Biljn. Zašt. 2002, 1, 37-41.

16. Bažok, R.; Šatvar, M.; Radoš, I.; Drmić, Z.; Lemić, D.; Čačija, M.; Gašparić, H.V. Comparative efficacy of classical and biorational insecticides on sugar beet weevil Bothynoderes punctiventris Germar (Coleoptera: Curculionidae). Plant Protect. Sci. 2016, 52, 134-141. [CrossRef]

17. Hauer, M.; Hansen, A.L.; Manderyck, B.; Olsson, Å.; Raaijmakers, E.; Hanse, B.; Stockfisch, N.; Märländer, B. Neonicotinoids in sugar beet cultivation in Central and Northern Europe: Efficacy and environmental impact of neonicotinoid seed treatments and alternative measures. Crop Prot. 2017, 1, 132-142. [CrossRef]

18. Epperlein, K.; Schmidt, H.W. Effects of pelleting sugarbeet seed with Gaucho ${ }^{\circledR}$ (imidacloprid) on associated fauna in the agricultural ecosystem. Pflanzenschutz-Nachr. Bayer 2001, 54, 369-398.

19. Zhang, L.P.; Greenberg, S.M.; Zhang, Y.M.; Liu, T.X. Effectiveness of thiamethoxam and imidacloprid seed treatments against Bemisia tabaci (Hemiptera: Aleyrodidae) on cotton. Pest Manag. Sci. 2011, 67, 226-232. [CrossRef]

20. Nuyttens, D.; Devarrewaere, W.; Verbovenb, P.; Foqu'ea, D. Pesticide-laden dust emission and drift from treated seeds during seed drilling: A review. Pest Manag. Sci. 2013, 69, 564-575. [CrossRef]

21. Gray, S.M.; Bergstrom, G.C.; Vaughan, R.; Smith, D.M.; Kalb, D.W. Insecticidal control of cereal aphids and its impact on the epidemiology of the barley yellow dwarf luteoviruses. Crop Prot. 1996, 15, 687-697. [CrossRef]

22. Nault, B.A.; Taylor, A.G.; Urwiler, M.; Rabaey, T.; Hutchison, W.D. Neonicotinoid seed treatments for managing potato leafhopper infestations in snap bean. Crop Prot. 2004, 23, 147-154. [CrossRef]

23. Alix, A.; Chauzat, M.P.; Clement, H.; Lewis, G.; Maus, C.; Miles, M.J. Guidance for the assessment of risks to bees from the use of plant protection products applied as seed coating and soil applications-Conclusions of the ICPBR dedicated working group. Julius-Kuhn-Arch. 2009, 423, 15-27.

24. Paulsrud, B.E.; Martin, D.; Babadoost, M.; Malvick, D.; Weinzierl, R.; Lindholm, D.C.; Steffey, K.; Pederson, W.; Reed, M.; Maynard, R. Oregon Pesticide Applicator Training Manual. Seed Treatment; University of Illinois Board of Trustees: Urbana, IL, USA, 2001.

25. EFSA (European Food Safety Authority). Conclusion on the peer review of the pesticide risk assessment for bees for the active substance clothianidin considering the uses as seed treatments and granules. EFSA J. 2018, 16, 5177. [CrossRef]

26. EFSA (European Food Safety Authority). Conclusion on the peer review of the pesticide risk assessment for bees for the active substance imidacloprid considering the uses as seed treatments and granules. EFSA J. 2018, 16, 5178. [CrossRef]

27. EFSA (European Food Safety Authority). Conclusion on the peer review of the pesticide risk assessment for bees for the active substance thiamethoxam EFSA J. 2018, 16, 5179. [CrossRef]

28. European Commission. Commission Implementing Regulation (EU) No 485/2013. Official Journal of the European Union 2013, L 139/12. Available online: https:/eur-lex.europa.eu/eli/reg_impl/2013/485/oj (accessed on 10 November 2017).

29. European Commission, Neonicotinoids. Available online: https://ec.europa.eu/food/plant/pesticides/approval_ active_substances/approval_renewal/neonicotinoids_en (accessed on 7 November 2017). 
30. Simon-Delso, N.; Amaral-Rogers, V.; Belzunces, L.P.; Bonmatin, J.M.; Chagnon, M.; Downs, C.; Furlan, L.; Gibbons, D.W.; Giorio, C.; Girolami, V.; et al. Systemic insecticides (neonicotinoids and fipronil): Trends, uses, mode of action and metabolites. Environ. Sci. Pollut. Res. 2015, 22, 5-34. [CrossRef]

31. Gylling Data Management Inc. ARM 9®GDM Software, Revision 2018.3; (B = 15650); Gylling Data Management Inc.: Brookings, SD, USA, 25 May 2018.

32. Kozina, A.; Čačija, M.; Barčić, J.I.; Bažok, R. Influence of climatic conditions on the distribution, abundance and activity of Agriotes lineatus L. adults in sex pheromone traps in Croatia. Int. J. Biometeorol. 2012, 57, 509-519. [CrossRef]

33. Kozina, A.; Lemić, D.; Bažok, R.; Mikac, K.M.; Mclean, C.M.; Ivezić, M.; Igrc Barčić, J. Climatic, Edaphic Factors and Cropping History Help Predict Click Beetle (Agriotes spp.) Abundance. J. Insect Sci. 2015, 15, 100-101. [CrossRef]

34. Čačija, M. Žičnjaci. In Šećerna Repa: Zaštita od Štetnih Organizama u Sustavu Integrirane Biljne Proizvodnje; Bažok, R., Ed.; Sveučilište u Zagrebu Agronomski Fakultet: Zagreb, Croatia, 2015; pp. 31-35.

35. Čačija, M.; Kozina, A.; Barčić, J.I.; Bažok, R. Linking climate change and insect pest distribution: An example using Agriotes ustulatus Shall. (Coleoptera: Elateridae). Agric. For. Entomol. 2018, 20, 288-297. [CrossRef]

36. European Commission. Commission Regulation (EU) No 491/2014 of 5 May 2014 amending Annexes II and III to Regulation (EC) No 396/2005 of the European Parliament and of the Council as regards maximum residue levels for ametoctradin, azoxystrobin, cycloxydim, cyfluthrin, dinotefuran, fenbuconazole, fenvalerate, fludioxonil, fluopyram, flutriafol, fluxapyroxad, glufosinate-ammonium, imidacloprid, indoxacarb, MCPA, methoxyfenozide, penthiopyrad, spinetoram and trifloxystrobin in or on certain products (1). Official Journal of the European Union 2014, L 146. Available online: https://eur-lex.europa.eu/legal-content/EN/TXT/?uri=OJ: L:2014:146:TOC (accessed on 7 November 2017).

37. European Commission. Commission Regulation (EU) 2017/671 of 7 April 2017 amending Annex II to Regulation (EC) No 396/2005 of the European Parliament and of the Council as regards maximum residue levels for clothianidin and thiamethoxam in or on certain products. Official Journal of the European Union 2017, L 97/9. Available online: https://eur-lex.europa.eu/legal-content/EN/TXT/?uri=uriserv:OJ.L_.2017.097. 01.0009.01.ENG\&toc=OJ:L:2017:097:TOC (accessed on 7 November 2017).

38. Wollweber, D.; Tietjen, K. Chloronicotinyl Insecticides: A Success of the New Chemistry. In Nicotinoid Insecticides and the Nicotinic Acetylcholine Receptor; Yamamoto, I., Casida, J.E., Eds.; Springer: Tokyo, Japan, 1999; pp. 109-125. [CrossRef]

39. Ester, A.; De Putter, H.; Van Bilsen, J.G. Filmcoating the seed of cabbage (Brassica oleracea L. convar. capitata L.) and cauliflower (Brassica oleracea L. var. botrytis L.) with imidacloprid and spinosad to control insect pests. Crop Protect. 2003, 22, 761-768. [CrossRef]

40. Lanka, S.K.; Stout, M.J.; Beuzelin, J.M.; Ottea, J.A. Activity of chlorantraniliprole and thiamethoxam seed treatments on life stages of the rice water weevil as affected by the distribution of insecticides in rice plants. Pest Manag. Sci. 2014, 20, 338-344. [CrossRef] [PubMed]

41. Bonmatin, J.M.; Moineau, I.; Charvet, R.; Collin, M.E.; Fleche, C.; Bengsch, E.R. Behavior of imidacloprid in fields. Toxicity for honey bees. In Environmental Chemistry; Lichtfouse, E., Schwarzbauer, J., Robert, D., Eds.; Springer: Berlin/Heidelberg, Germany, 2005; pp. 483-494. [CrossRef]

42. Alford, A.; Krupke, C.H. Translocation of the neonicotinoid seed treatment clothianidin in maize. PLoS ONE 2017, 12, e0186527. [CrossRef]

43. Gupta, S.; Gajbhiye, V.T.; Gupta, R.K. Soil dissipation and leaching behavior of a neonicotinoid insecticide thiamethoxam. Bull. Environ. Contam. Toxicol. 2008, 80, 431-437. [CrossRef] [PubMed]

44. Huseth, A.S.; Groves, R.L. Environmental Fate of Soil Applied Neonicotinoid Insecticides in an Irrigated Potato Agroecosystem. PLoS ONE 2014, 9, e97081. [CrossRef]

45. Guzsvány, V.; Csanádi, J.; Gaál, F. NMR study of the influence of $\mathrm{pH}$ on the persistence of some neonicotinoids in water. Acta Chim. Slov. 2006, 53, 52-57.

46. Cox, W.J.; Shields, E.; Cherney, J.H. Planting date and seed treatment effects on soybean in the Northeastern United States. Agron. J. 2008, 100, 1662-1665. [CrossRef]

47. Krohn, J.; Hellpointer, E. Environmental fate of imidacloprid. Pflanzenschutz-Nachr. Bayer (Spec. Ed.) 2002, 55, 1-26.

48. Maienfisch, P.; Brandl, F.; Kobel, W.; Rindlisbacher, A.; Senn, R. CGA 293,343: A novel, broad-spectrum neonicotinoid insecticide. In Neonicotinoid Insecticides and the Nicotinic Acetylcholine Receptor; Yamamoto, I., Casida, J.E., Eds.; Springer: New York, NY, USA, 1999; pp. 177-209. 
49. Goulson, D. An overview of the environmental risks posed by neonicotinoid insecticides. J. Appl. Ecol. 2013, 50, 977-987. [CrossRef]

50. Krupke, C.H.; Holland, J.D.; Long, E.Y.; Eitzer, B.D. Planting of neonicotinoid-treated maize poses risks for honey bees and other non-target organisms over a wide area without consistent crop yield benefit. J. Appl. Ecol. 2017, 54, 1449-1458. [CrossRef]

51. Westwood, F.; Bean, K.M.; Dewar, A.M.; Bromilow, R.H.; Chamberlain, K. Movement and persistence of (14C)imidacloprid in sugar-beet plants following application to pelleted sugar-beet seed. Pestic. Sci. 1999, 52, 97-103. [CrossRef]

52. Bažok, R.; Barčić, J.I.; Dragović-Uzelac, V.; Kos, T.; Drmić, Z.; Zorić, Z.; Pedisić, S.; Cathleen, J.; Hapeman, C.J. Sugar beet seed treatments with neonicotinoids: Do they pose a risk for bees? In Proceedings of the 13th IUPAC International Congress Of Pesticide Chemistry Crop, Environment and Public Health Protection Technologies for a Changing Word, San Francisco, CA, USA, 10-14 August 2014.

53. Armbruster, D.A.; Pry, T. Limit of Blank, Limit of Detection and Limit of Quantitation. Clin. Biochem. Rev. 2008, 29 (Suppl. 1), 49-52.

Publisher's Note: MDPI stays neutral with regard to jurisdictional claims in published maps and institutional affiliations.

(C) 2020 by the authors. Licensee MDPI, Basel, Switzerland. This article is an open access article distributed under the terms and conditions of the Creative Commons Attribution (CC BY) license (http://creativecommons.org/licenses/by/4.0/). 